Bull. Chem. Soc. Ethiop. 2013, 27(3), 395-404.

Printed in Ethiopia

ISSN 1011-3924

DOI: http://dx.doi.org/10.4314/bcse.v27i3.8

(c) 2013 Chemical Society of Ethiopia

\title{
SYNTHESIS, CHARACTERIZATION AND ANTIBACTERIAL PROPERTIES OF SOME TRANSITION METAL COMPLEXES OF (1H-PYRROL-2-YL)- ISONICOTINOYLHYDRAZONE
}

\author{
Evans N. Mainsah ${ }^{1}$, Peter T. Ndifon ${ }^{2 *}$, Emmanuel N. Nfor $^{1}$ and Julius N. Njapba ${ }^{1}$ \\ ${ }^{1}$ Department of Chemistry, University of Buea, P.O. Box 63, Buea, Cameroon \\ ${ }^{2}$ Coordination Chemistry Laboratory, Department of Inorganic Chemistry, University of \\ Yaoundé1, P.O. Box 812 Yaoundé, Cameroon
}

(Received October 11, 2012; revised July 2, 2013)

\begin{abstract}
A new ligand, (1H-pyrrol-2-yl)isonicotinoylhydrazone (Pyr-inh) and its metal complexes have been synthesised and characterized by elemental analyses, IR, ${ }^{1} \mathrm{H}$ and ${ }^{13} \mathrm{C}-\mathrm{NMR}$, UV-Vis spectra, molar conductance, and thermogravimetry-differential thermal analysis (TG-DTA). From the results obtained, the structure of the complexes are of general formula $\left[\mathrm{M}(\mathrm{Pyr}-\mathrm{inh})_{2} \mathrm{Cl}_{2}\right] \cdot \mathrm{xH}_{2} \mathrm{O}$ for $\mathrm{M}=\mathrm{Co}(\mathrm{II})$, and $\mathrm{Zn}(\mathrm{II})$ and $[\mathrm{M}(\mathrm{Pyr}-$ inh $\left.)_{2}\left(\mathrm{H}_{2} \mathrm{O}\right)_{2}\right] \mathrm{Cl}_{2}$ for $\mathrm{Cu}$ (II). The thermal behaviour of these complexes showed the loss of lattice water in the first step followed by decomposition of the ligand in subsequent steps. The ligand and its transition metal complexes were studied for their in vitro antibacterial activity against ten pathogenic bacterial strains. The data obtained revealed that the ligand was active against Morganella morganii and Escherichia coli, the Co(II) complex active against Klebsiella oxytoca, the $\mathrm{Cu}$ (II) complex showed significant activity against five out of the ten bacterial strains and the $\mathrm{Zn}$ (II) complex was active against all the pathogenic bacterial strains investigated.
\end{abstract}

KEY WORDS: (1H-pyrrol-2-yl)isonicotinoylhydrazone, Metal complexes, Schiff base, Synthesis, Thermal analysis, Antibacterial activity

\section{INTRODUCTION}

There has been considerable interest in Schiff bases due to the role they played in coordination chemistry as they readily form stable Schiff base complexes with most transition metals [1-3]. Schiff bases and their metal complexes exhibit a broad range of potential applications because of their structural diversity and intrinsic magnetic properties and have been shown to be potential antibacterial [4-15] and anticancer [16-18] agents. The past few decades have seen the introduction of a number of pharmaceutical compounds which contain five, six, and sevenmembered rings such as piperazines, piperidines, imidazoles, benzodiazepines, and other heterocycles containing nitrogen, sulfur, and oxygen [1]. The tuberculostatic activity of isonicotinic acid hydrazide and its aroylhydrazones containing azomethine nitrogen is attributed to their ability to form stable complexes with d- and f-block metal ions [19-21]. The upsurge interest in hydrazones is due to their antimicrobial, antituberculosis, and antitumor activity [2224].

The increasing resistance to antibacterial drugs has necessitated the search for new compounds with potential effects against pathogenic bacteria. The incorporation of metals or metal-based systems into molecules of antibacterial or antifungal agents is expected to enhance the bactericidal or fungicidal properties of these drugs and to improve on the activity of compounds with less potentials [4-15]. We have been interested in studying the effect of ligand modification on their physicochemical and biological properties [25, 26].

Isoniazid (INH) is a prodrug of proven therapeutic importance and is used against a broad spectrum of bacterial infections [27]. It is a potent, highly selective antimycobacterial agent

${ }^{*}$ Corresponding author. E-mail: pndifon@yahoo.com 
used against the mycobacterium tuberculosis probably because of its ability to form stable complexes with transition metal ions in living systems. In view of the biological and medicinal properties of this compound, we developed an interest to synthesize a Schiff base derived from isoniazid and pyrrole-2-carboxaldehyde, with the hope of developing metal-based biologically active adducts that could act against resistant bacterial species. We here report on the synthesis, characterisation and biological activities of some transition metal complexes of (1H-pyrrol-2-yl) isonicotinoylhydrazone, Pyr-inh a Schiff base, derived from isoniazid and pyrrole-2carboxaldehyde.

\section{EXPERIMENTAL}

\section{Materials}

All chemicals were of analytical AR grade and were used as supplied without further purification. The solvents were doubly distilled according to standard methods. Pyrrole-2carboxaldehyde was obtained from Acros Organics, isoniazid from BDH Chemicals Ltd, and $\mathrm{CuCl}_{2} \cdot 2 \mathrm{H}_{2} \mathrm{O}, \mathrm{ZnCl}_{2}$ and $\mathrm{CoCl}_{2} \cdot 6 \mathrm{H}_{2} \mathrm{O}$ from Prolabo Reagents.

\section{Physical measurements}

${ }^{1} \mathrm{H}-\mathrm{NMR}$ and ${ }^{13} \mathrm{C}-\mathrm{NMR}$ spectra were recorded with a $500 \mathrm{MHz}$ Bruker DRX500 spectrophotometer in dimethylsulfoxide (DMSO) as solvent and were reported relative to tetramethylsilane (TMS) as internal standard. The analysis of CHN contents of the ligand and metal complexes were performed on a Euro elemental analyser (Euro vector design). Chloride was estimated by Volhard's method and metal(II) content by gravimetric method. Conductivity measurements of the metal complexes were determined using a VERNIER LabPro device. Thermogravimetric analyses were carried out using a TGA Perkin-Elmer STA 6000 simultaneous thermal analyzer under a nitrogen atmosphere. IR Spectra were recorded with a Vector 220 FT-IR Spectrophotometer on KBr disc. UV-Visible spectra were recorded on a Shimadzu double-beam spectrophotometer; model UV-150-02 using DMSO as reference.

Synthesis of (1H-pyrrol-2-yl)isonicotinoylhydrazone (Pyr-inh)

Isoniazid $(0.288 \mathrm{~g}, 2.1 \mathrm{mmol})$ dissolved in $10 \mathrm{~mL}$ of methanol was added to pyrrole-2carboxaldehyde $(0.395 \mathrm{~g}, 2.1 \mathrm{mmol})$ dissolved in $10 \mathrm{~mL}$ of methanol. The mixture was heated under reflux with continuous stirring at about $60{ }^{\circ} \mathrm{C}$ for $24 \mathrm{~h}$ during which a light brown solution was obtained. The solution was allowed to cool with the formation of light-brown needle-like precipitate. The precipitate was then filtered and dried over anhydrous calcium chloride in a desiccator at room temperature. The formation of the Schiff base was monitored by TLC and its purity was checked by melting point determination and elemental analyses.

\section{Preparation of metal complexes}

A general method was used for the synthesis of the metal complexes. These metal complexes were prepared by mixing warm methanolic solutions $\left(0.5 \mathrm{mmol}\right.$ of the metal salts $\left(\mathrm{CoCl}_{2} \cdot 6 \mathrm{H}_{2} \mathrm{O}\right.$, $\mathrm{CuCl}_{2} \cdot 2 \mathrm{H}_{2} \mathrm{O}$ and $\mathrm{ZnCl}_{2}$ dissolved in $10 \mathrm{~mL}$ of methanol) and warm methanolic solutions of the ligand $(1.0 \mathrm{mmol}$ in $10 \mathrm{~mL}$ of methanol). The mixtures were heated under reflux with continuous stirring for 3-4 h, during which the complexes separated out, filtered and washed three times with methanol and dried over anhydrous $\mathrm{CaCl}_{2}$ in a descicator. 
Biological activity

The ligand and its metal complexes were screened for in vitro antimicrobial activity in DMSO against ten bacterial strains (Staphylococcus aureus, Salmonella typhi, Proteus vulgaris, Enterobacter cloacae, Morganella morganii, Escherichia coli, Citrobacter freundii, Shigella flexneri, Klebsiella pneumoniae and Klebsiella oxytoca). All the bacterial strains were obtained from the Medical Bacteriology Laboratory of Centre Pasteur du Cameroon, Yaoundé Cameroon. The microbial isolates were maintained on an agar slant at $4{ }^{\circ} \mathrm{C}$ and the strains were sub-cultured on an appropriate fresh agar plate, $24 \mathrm{~h}$ prior antibacterial tests. Samples of the ligand, its metal complexes and the metal salts were diluted in DMSO and $1 \mathrm{mg} / \mathrm{mL}$ of each was placed on sterilized filter paper discs and allowed to dry. The reference antibiotic, gentamycin, was also prepared in the same manner in DMSO prior to testing. The antimicrobial diffusion tests were carried out as described by Berghe and Vlietink [27] using a cell suspension of about $1.5 \times 10^{6} \mathrm{CFU} / \mathrm{mL}$ obtained from the McFarland turbidity Standard No 0.5. The suspension was standardized by adjusting the optical density to 0.1 at $600 \mathrm{~nm}$ (Shimadzu UV-120-01 spectrophotometer). The suspension was used for inoculation by floating the surface of the CAM plates. When the excess liquid was allowed to dry under an aspirator hood, holes of 6-mm diameter were made in the medium and filled with $60 \mu \mathrm{L}$ of test samples.

\section{RESULTS AND DISCUSSION}

The condensation of isoniazid with pyrrole-2-carboxaldehyde yielded a new Schiff base (Scheme 1), which was used to prepare the transition metal complexes whose analytical data are presented in Table 1. All the complexes are coloured powders with high melting points. The complexes are non-hygroscopic and are stable in air, insoluble in methyl alcohol, ethyl alcohol, chloroform and acetone but very soluble in DMF and DMSO. The analytical data suggest a ratio of 1:2 (metal:ligand) for all the complexes. The room temperature molar conductivity measurements in DMSO indicated that the complexes are 2:1 electrolytes [28]. The elemental analytical data are consistent with the proposed formula.

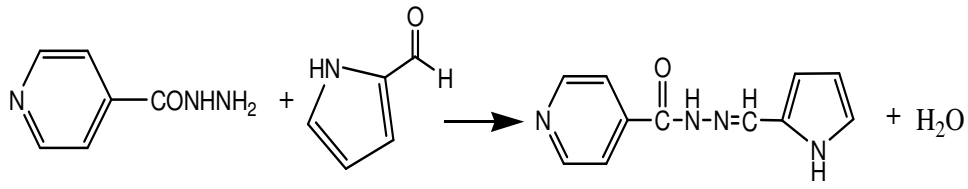

Scheme 1. Synthesis of (1H-pyrrol-2-yl) isonicotinoylhydrazone.

Table 1. Analytical and physical data of the ligand and its complexes.

\begin{tabular}{|c|c|c|c|c|c|c|c|c|}
\hline \multirow[t]{2}{*}{ Compound } & \multirow{2}{*}{$\begin{array}{l}\text { Colour } \\
\text { M.p. } /^{\circ} \mathrm{C}\end{array}$} & \multirow{2}{*}{$\begin{array}{c}\text { Yield } \\
\%\end{array}$} & \multirow{2}{*}{$\begin{array}{c}\Lambda^{\mathrm{a}} / \Omega^{-1} \mathrm{~cm}^{2} \\
\mathrm{~mol}^{-1}\end{array}$} & \multicolumn{5}{|c|}{$\begin{array}{l}\text { Elemental analysis } \\
\text { Found (calcd.) }\end{array}$} \\
\hline & & & & $\% \mathrm{C}$ & $\% \mathrm{~N}$ & $\% \mathrm{H}$ & $\% \mathrm{M}$ & $\% \mathrm{Cl}$ \\
\hline $\mathrm{C}_{11} \mathrm{H}_{10} \mathrm{~N}_{4} \mathrm{O}$ & $\begin{array}{c}\text { Light brown } \\
218 \pm 2\end{array}$ & 87.0 & - & $\begin{array}{c}61.02 \\
(61.68)\end{array}$ & $\begin{array}{c}26.38 \\
(26.17)\end{array}$ & $\begin{array}{c}4.02 \\
(4.67)\end{array}$ & - & - \\
\hline$\left[\mathrm{Cu}\left(\mathrm{C}_{11} \mathrm{H}_{10} \mathrm{~N}_{4} \mathrm{O}\right)_{2}\left(\mathrm{H}_{2} \mathrm{O}\right)_{2}\right] \mathrm{Cl}_{2}$ & $\begin{array}{c}\text { Dark green } \\
242 \pm 2\end{array}$ & 72.0 & 36.21 & $\begin{array}{c}46.93 \\
(46.10) \\
\end{array}$ & $\begin{array}{c}19.91 \\
(18.98) \\
\end{array}$ & $\begin{array}{c}3.56 \\
(3.87) \\
\end{array}$ & $\begin{array}{c}11.29 \\
(12.36) \\
\end{array}$ & \begin{tabular}{|c|}
12.62 \\
$(12.87)$ \\
\end{tabular} \\
\hline$\left[\mathrm{Zn}\left(\mathrm{C}_{11} \mathrm{H}_{10} \mathrm{~N}_{4} \mathrm{O}\right)_{2} \mathrm{Cl}_{2}\right] \cdot 2 \mathrm{H}_{2} \mathrm{O}$ & $\begin{array}{c}\text { Light yellow } \\
230 \pm 2 \\
\end{array}$ & 66.6 & 34.14 & $\begin{array}{c}46.78 \\
(47.20) \\
\end{array}$ & $\begin{array}{c}19.84 \\
(18.78) \\
\end{array}$ & $\begin{array}{c}3.54 \\
(4.32) \\
\end{array}$ & $\begin{array}{c}11.59 \\
(12.10) \\
\end{array}$ & \begin{tabular}{|c|}
12.58 \\
$(12.87)$ \\
\end{tabular} \\
\hline$\left[\mathrm{Co}\left(\mathrm{C}_{11} \mathrm{H}_{10} \mathrm{~N}_{4} \mathrm{O}\right)_{2} \mathrm{Cl}_{2}\right] \cdot 2 \mathrm{H}_{2} \mathrm{O}$ & $\begin{array}{l}\text { Brown } \\
256 \pm 2\end{array}$ & 21.2 & 23.79 & $\begin{array}{c}47.32 \\
(47.64) \\
\end{array}$ & $\begin{array}{c}20.08 \\
(21.50) \\
\end{array}$ & $\begin{array}{c}3.58 \\
(3.78)\end{array}$ & $\begin{array}{c}10.55 \\
(10.02) \\
\end{array}$ & $\begin{array}{c}12.73 \\
(13.04) \\
\end{array}$ \\
\hline
\end{tabular}


IR spectra

A comparative study of the IR spectra of the complexes with that of the ligand indicated that bands due to $v(\mathrm{C}=\mathrm{O})$ of the ligand at $1700 \mathrm{~cm}^{-1}$ and $v(\mathrm{NH})$ at $3240 \mathrm{~cm}^{-1}$ were absent in the spectra of the respective complexes (Table 2). This is presumably due to amide-imidol tautomerism (Scheme 2) and their subsequent coordination through the imidol oxygen [29]. Bands at $1600 \mathrm{~cm}^{-1}$ due to $v(\mathrm{C}=\mathrm{N})$ of the ligand shifted to lower wave number in the complexes $1565-1575 \mathrm{~cm}^{-1}$ indicating the coordination of the azomethine nitrogen. Non ligand bands at $420-427 \mathrm{~cm}^{-1}$ and $510-520 \mathrm{~cm}^{-1}$ were assigned to $v(\mathrm{M}-\mathrm{O})$ and $v(\mathrm{M}-\mathrm{N})$, respectively. In the ligand, the band at $1581 \mathrm{~cm}^{-1}$ due to the pyridine ring nitrogen remained unchanged on complexation indicating the non involvement of the ring nitrogen in the complexation [30]. The overall IR spectral evidence suggests that the ligand is bidentate in nature, coordinating through amide-oxygen and azomethine nitrogen with the formation of a five membered chelate ring. The spectra of all complexes exhibited intense broad bands at $3400-3450 \mathrm{~cm}^{-1}$ due to $v(\mathrm{OH})$ of the lattice water molecule(s) $[27,31]$. The presence of the lattice water molecules was also confirmed by elemental and thermogravimmetric analysis.

Table 2. Selected infrared absorption bands $\left(\mathrm{cm}^{-1}\right)$ of ligand and its complexes.

\begin{tabular}{|l|c|c|c|c|c|c|c|}
\hline Compound & $v(\mathrm{OH})$ & $v(\mathrm{C}=\mathrm{N})$ & $v(\mathrm{C}=\mathrm{O})$ & $v(\mathrm{~N}-\mathrm{H})$ & $v($ Py-ring $)$ & $v(\mathrm{M}-\mathrm{N})$ & $v(\mathrm{M}-\mathrm{O})$ \\
\hline $\mathrm{C}_{11} \mathrm{H}_{10} \mathrm{~N}_{4} \mathrm{O}$ & - & 1600 & 1700 & 3240 & 1581 & - & - \\
\hline$\left[\mathrm{Cu}\left(\mathrm{C}_{11} \mathrm{H}_{10} \mathrm{~N}_{4} \mathrm{O}\right)_{2}\left(\mathrm{H}_{2} \mathrm{O}\right)_{2}\right] \mathrm{Cl}_{2}$ & 3400 & 1570 & 1650 & 3200 & 1581 & 520 & 420 \\
\hline$\left[\mathrm{Zn}\left(\mathrm{C}_{11} \mathrm{H}_{10} \mathrm{~N}_{4} \mathrm{O}\right)_{2} \mathrm{Cl}_{2}\right] \cdot 2 \mathrm{H}_{2} \mathrm{O}$ & 3450 & 1565 & 1680 & 3214 & 1580 & 518 & 427 \\
\hline$\left[\mathrm{Co}\left(\mathrm{C}_{11} \mathrm{H}_{10} \mathrm{~N}_{4} \mathrm{O}\right)_{2} \mathrm{Cl}_{2}\right] \cdot 2 \mathrm{H}_{2} \mathrm{O}$ & 3400 & 1575 & 1650 & 3205 & 1580 & 510 & 424 \\
\hline
\end{tabular}

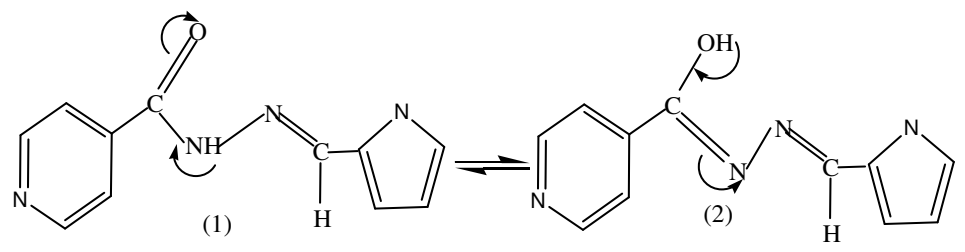

Scheme 2. Tautomeric forms of the ligand showing (1) amide form and (2) imidol form.

\section{NMR spectra}

The ${ }^{1} \mathrm{H}$ NMR spectral data of the ligand and the corresponding metal complexes were recorded in DMSO- $\mathrm{d}_{6}$ with TMS as an internal standard. A comparative study of the ${ }^{1} \mathrm{H}$ NMR spectra of the ligand and its metal complexes indicated the disappearance of the $\mathrm{NH}$ proton signal at $\delta$ 11.62 in the complexes which is considered as an additional evidence of enolization of the ligand during complexation [32]. The free ligand exhibited a signal at $\delta 8.51$ which was assigned to $\alpha$-protons of the pyridine ring and multiplet signals observed between $\delta 6.97$ and $\delta$ 8.27 and assigned to $\beta$-protons of the pyridine ring and the aromatic ring protons [33].

The ${ }^{13} \mathrm{C}$ NMR data of the ligand indicated signals due to carbon attached to the azomethine nitrogen and enolic oxygen at $\delta 141.3$ and $\delta 161.6$, respectively. Thus, the ${ }^{1} \mathrm{H}-\mathrm{NMR}$ and ${ }^{13} \mathrm{C}$ NMR spectra confirmed the monobasic bidentate nature of the ligand, already suggested by the IR spectral studies. 


\section{Electronic spectra}

The electronic absorption spectra of the complexes were recorded in DMF solution. The electronic spectrum of the $\mathrm{Cu}$ (II) complex showed large bands at $26667 \mathrm{~cm}^{-1}$ and $38462 \mathrm{~cm}^{-1}$ while the electronic spectrum of $\mathrm{Zn}$ (II) complex exhibited two bands at $28571 \mathrm{~cm}^{-1}$ and 38462 $\mathrm{cm}^{-1}$. Furthermore the electronic spectrum of the Co(II) complex exhibited two bands at 28571 $\mathrm{cm}^{-1}$ and $38462 \mathrm{~cm}^{-1}$. The absorption bands observed at $26667 \mathrm{~cm}^{-1}$ and $28571 \mathrm{~cm}^{-1}$ are assignable to a combination of $\mathrm{d}-\mathrm{d}$ bands and metal-ligand charge transfer $(\mathrm{M} \rightarrow \mathrm{LCT})$ [34, 35]. The electronic spectra measurements is indicative of octahedral geometry for the $\mathrm{Cu}$ (II) complex, a tetrahedral geometry for the $\mathrm{Zn}$ (II) complex and a square planar geometry for the Co(II) complex

\section{Thermal studies}

Thermal analysis has proved to be useful in determining the crystal water content in complexes and their thermal stability and decomposition mode under a controlled heating rate. Thermogravimetric (TG) and differential thermal analyses (DTA) were used to describe the thermal behaviour of the prepared complexes. The typical TG-DTA analysis of the complexes was performed from 20 to $320{ }^{\circ} \mathrm{C}$ at a heating rate of $5 \mathrm{~K} \mathrm{~min}^{-1}$ under dynamic air condition. The decomposition of $\mathrm{Cu}(\mathrm{II})$ complex takes place in two stages as shown in Figure 1.

The TG/DTA curve of the $\mathrm{Cu}$ (II) complex show mass loss between $40-145{ }^{\circ} \mathrm{C}$ with DTA endothermic peak at $84{ }^{\circ} \mathrm{C}$ due to the dehydration with loss of coordinated water molecules. The mass loss observed in this step is $9.12 \%$. The second stage between $145-300{ }^{\circ} \mathrm{C}$ with DTA endothermic peak at $185^{\circ} \mathrm{C}$ is due to decomposition of the ligand molecule. The degradation of the molecule was further confirmed by two exothermic peaks at $226{ }^{\circ} \mathrm{C}$ and $296{ }^{\circ} \mathrm{C}$ with $27.7 \%$ mass loss.

The TG/DTA curve for the $\mathrm{Zn}$ (II) complex is shown in Figure 2. Thermal decomposition of the $\mathrm{Zn}$ (II) complex occurs in three stages and takes place between $40-130{ }^{\circ} \mathrm{C}$ with mass loss of $9.22 \%$, attributed to the loss of two moles of lattice water. Two endothermic peaks at $40{ }^{\circ} \mathrm{C}$ and $100{ }^{\circ} \mathrm{C}$ are observed in the DTA curve. The second stage (from $130-228{ }^{\circ} \mathrm{C}$ ) is attributed to the decomposition of the ligand moiety. A sharp endothermic peak at $200{ }^{\circ} \mathrm{C}$ is noticed with an observed mass loss of $10.39 \%$. The third stage occurred between $228-304{ }^{\circ} \mathrm{C}$ with mass loss of $12.31 \%$ which may be attributed to the total decomposition of the ligand molecule.

The TG/DTA curves of the Co(II) complex are represented in Figure 3. The Co(II) complex shows almost three stage process as with $\mathrm{Zn}$ (II) complex. The first decomposition stage occurs in the temperature range $40-104{ }^{\circ} \mathrm{C}$ with a mass loss of $16.34 \%$ attributed to the dehydration and loss of lattice water corresponding to an endothermic effect at $60{ }^{\circ} \mathrm{C}$. The second decomposition stage occurred between $104-176{ }^{\circ} \mathrm{C}$ with a mass of loss of $7.43 \%$ attributed to the decomposition of the ligand moiety. A broad exothermic peak at $94{ }^{\circ} \mathrm{C}$ was also observed. The third decomposition occurred between $176-304{ }^{\circ} \mathrm{C}$ with mass loss of $28.8 \%$ having an endothermic peak at $236{ }^{\circ} \mathrm{C}$ and a broad exothermic peak at $270{ }^{\circ} \mathrm{C}$ and attributed to the total decomposition of the ligand.

Based on the above analytical and spectral data together with the thermal decomposition studies, the complexes have the structural formula as depicted in Figure 4. 


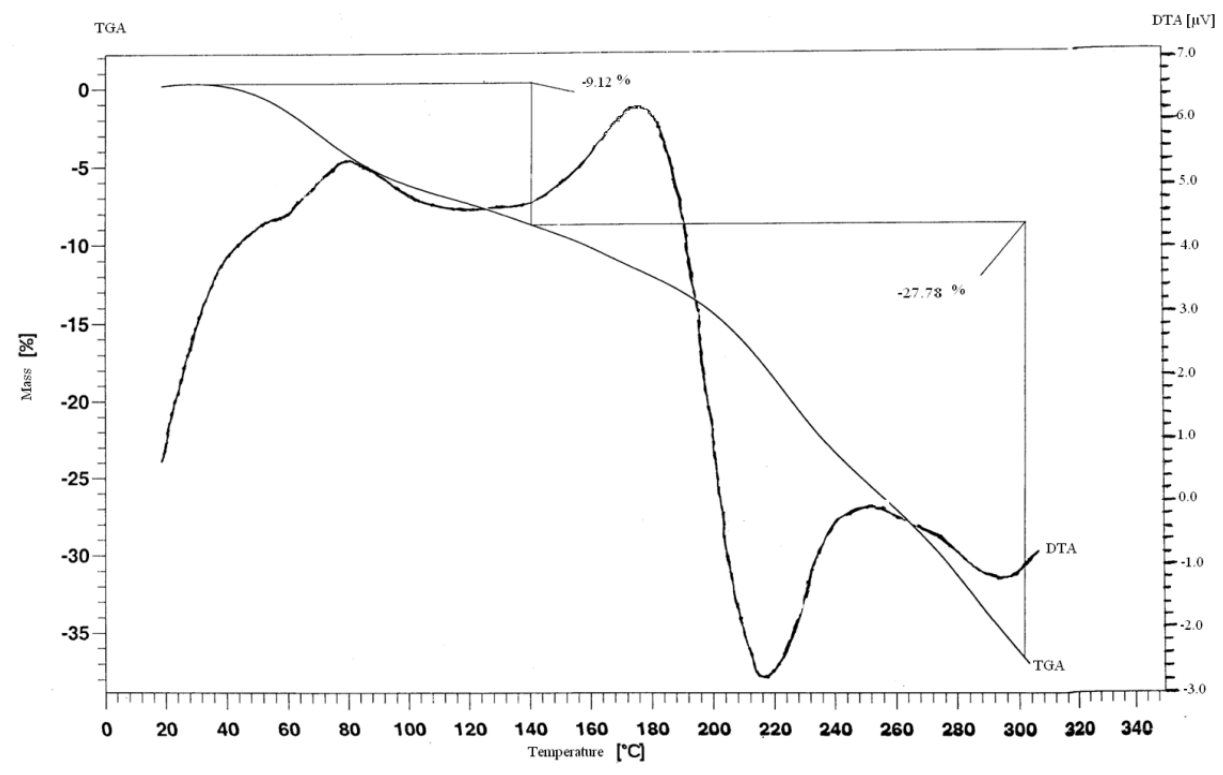

Figure 1. TGA and DTA thermograms of $\mathrm{Cu}$ (II) complex.

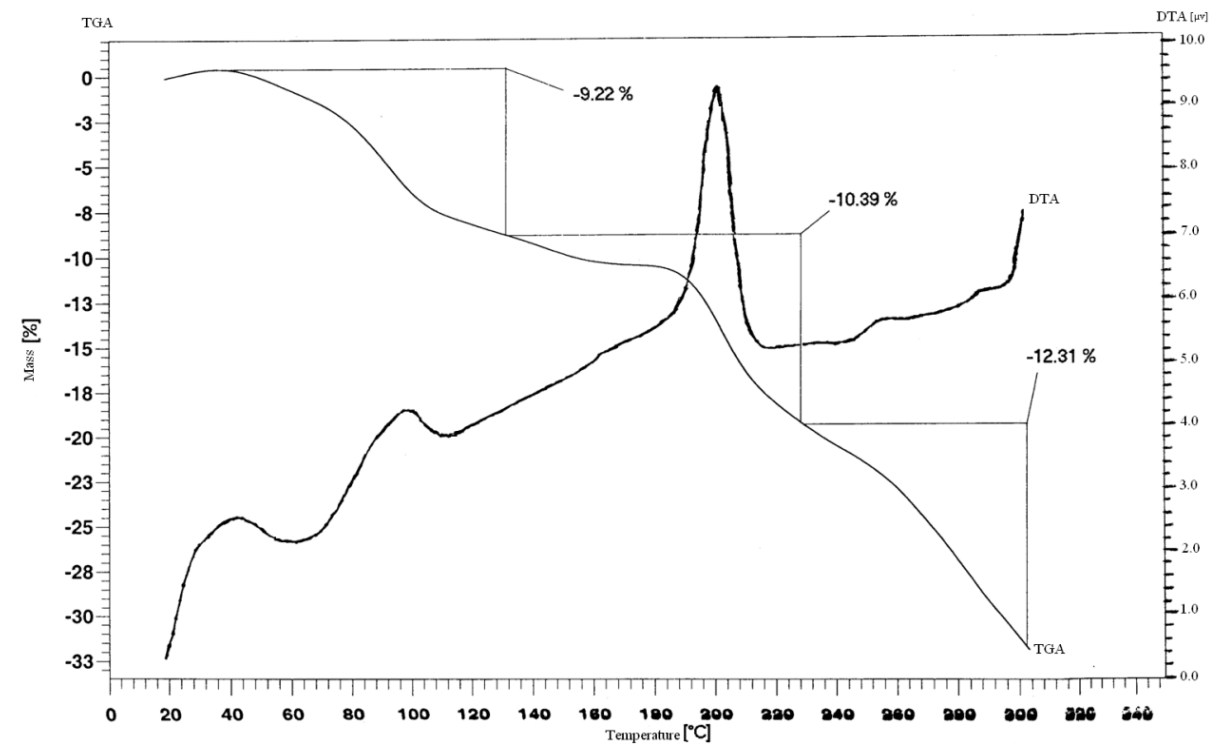

Figure 2. TGA and DTA thermograms of Zn(II) complex. 


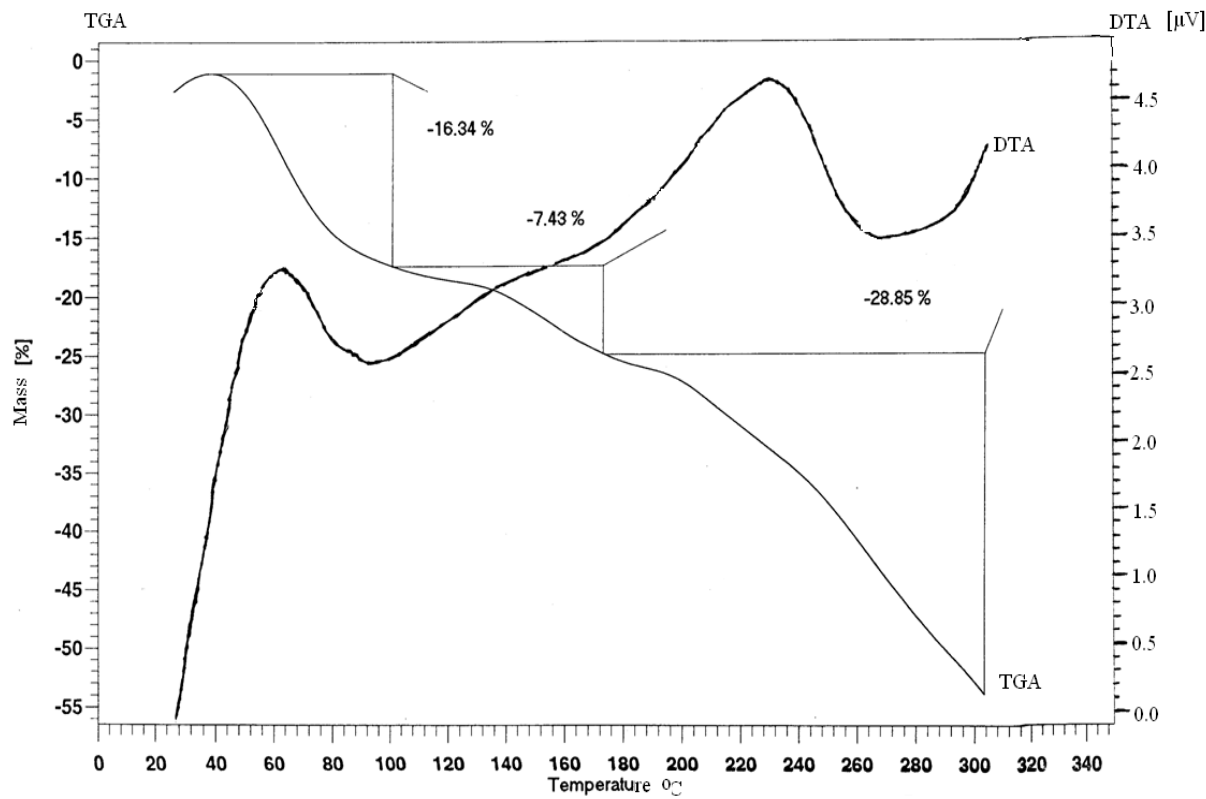

Figure 3. TGA and DTA thermograms of Co(II) complex.

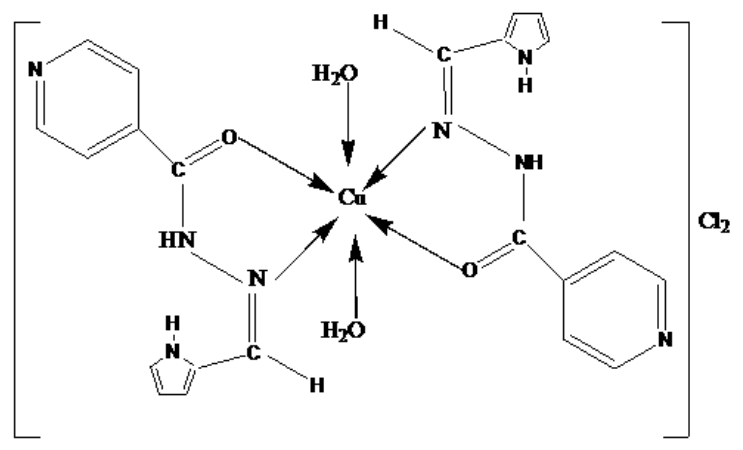

Figure 4. Proposed structure of the $\mathrm{Cu}(\mathrm{II})$ complexes.

\section{Biological activity}

Antibacterial activity of the ligand and its metal complexes were tested in vitro by the discdiffusion method [36] against ten bacterial stains (Salmonella typhi, Staphylococcus aureus, Proteus vulgaris, Enterobacter clocae, Morganella morganii, Escherichia coli, Citrobacter freundii, Shigella flexneri, Klebsiella pneumoniae and Klebsiella oxytoca). Holes with methanol were used as negative control. The plates were inoculated at $37{ }^{\circ} \mathrm{C}$ for $24 \mathrm{~h}$. Antimicrobial activity was evaluated by measuring the diameter of the inhibition zone (IZ) around the hole. The assay was repeated thrice and results recorded as mean \pm standard deviation of triplicated experiments. Compounds were considered as active when the IZ was greater than $6 \mathrm{~mm}$. 
The diameter of the susceptibility zones were measured in $\mathrm{mm}$ and the results are presented in Table 3. The ligand, INH-PYR, was found to be active against Morganella morganii and Escherichia coli. The $\mathrm{Cu}$ (II) complex showed significant activity against two out of the five bacterial strains (Klebsiella pneumoniae and Klebsiella oxytoca). The Co(II) complex showed significant activity against Klebsiella oxytoca. Isoniazid, INH one of the reagents for the synthesis of the Schiff base is an antibiotic in clinical use. It showed moderate activity against Klebsiella pneumoniae while pyrrole-2-carboxaldehyde, another reagent was inactive to all the bacterial strains.

Table 3. Antibacterial screening data for the ligand and its complexes.

\begin{tabular}{|l|c|c|c|c|c|}
\hline \multirow{2}{*}{ Compound } & \multicolumn{5}{|c|}{ Diameter of inhibition zone (in mm) } \\
\cline { 2 - 6 } & S. typhi & M. morganii & E. coli & K. pneumoniae & K. oxytoca \\
\hline $\mathrm{C}_{11} \mathrm{H}_{10} \mathrm{~N}_{4} \mathrm{O}$ & 13 & 12 & 12 & 12 & 12 \\
\hline$\left[\mathrm{Cu}\left(\mathrm{C}_{11} \mathrm{H}_{10} \mathrm{~N}_{4} \mathrm{O}\right)_{2}\left(\mathrm{H}_{2} \mathrm{O}\right)_{2}\right] \mathrm{Cl}_{2}$ & - & - & - & 19 & 17 \\
\hline$\left[\mathrm{Zn}\left(\mathrm{C}_{11} \mathrm{H}_{10} \mathrm{~N}_{4} \mathrm{O}\right)_{2} \mathrm{Cl}_{2}\right] .2 \mathrm{H}_{2} \mathrm{O}$ & 13 & 8 & 16 & 14 & 12 \\
\hline$\left[\mathrm{Co}\left(\mathrm{C}_{11} \mathrm{H}_{10} \mathrm{~N}_{4} \mathrm{O}\right)_{2} \mathrm{Cl}_{2}\right] .2 \mathrm{H}_{2} \mathrm{O}$ & - & - & - & - & 11 \\
\hline $\mathrm{RA}(\mathrm{Gentamycin})$ & 26 & 26 & 25 & 11 & 22 \\
\hline
\end{tabular}

The $\mathrm{Zn}$ (II) complex showed antibacterial activity against all the five strains of microbes. In this case, it was moderately active against Morganella morganii and significantly active against the rest of the bacterial strains. The $\mathrm{Zn}$ (II) complex was significantly more active against Klebsiella pneumoniae than the reference antibiotic, gentamycin. All metal salts showed activity against all the strains of bacteria.

It is known that chelation tends to improve on the activity of the ligand thus rendering it a more powerful and potent antibactericidal agent than the parent organic ligand (Schiff base) [36]. A possible explanation is that, in the chelated complex, the positive charge of the metal is partially shared with the donor atoms in the ligand and there is $\pi$-electron delocalisation over the whole chelating ring. This, in turn, increases the lipophilic character of the metal chelate and favours its permeation through the lipid layers of the membranes of the micro-organism. Apart from this, other factors such as solubility, conductivity and dipole moment influenced by the presence of the metal ions may also be reasons for the increased activity.

\section{CONCLUSION}

We have been able to synthesise a new Schiff base ligand, (1H-pyrrol-2-yl) isonicotinoylhydrazone and reacted with $\mathrm{Co}(\mathrm{II}), \mathrm{Cu}$ (II) and $\mathrm{Zn}$ (II) ions to yield the corresponding metal complexes. This is a neutral ligand, with tridentate NNO donors derived from the the azomethine nitrogen atom, the pyrrole nitrogen atom and the carbonyl oxygen atom. Antibacterial activity of the ligand and its metal complexes reveal that the ligand and the $\mathrm{Zn}$ (II) complex exhibited remarkable antibacterial activities against some of the tested bacterial strains. The significant biological activity of the $\mathrm{Zn}$ (II) complex clearly demonstrated the effect of chelation on the biological activity of the ligand.

\section{ACKNOWLEDGEMENTS}

We are grateful to Prof. You Song and Prof. Dr. Rhett Kempe of the State Key Laboratory of Coordination Chemistry, Nanjing University, China and Inorganic Chemistry Institute, University of Bayreuth, Germany, respectively, for the spectral data. 


\section{REFERENCES}

1. Raman, N.; Raja J.S.; Sakthiel, A. J. Coord. Chem. 2009, 62, 691.

2. Nomiya, K.; Tsuda, K.; Kasuga, N.C. J.Chem. Soc. Dalton Trans. 1998, 1653.

3. Popov, L.D.; Tupolova, Y.P.; Levchenkov, S.I.; Lukov, V.V.; Kogan, V.A. Rus. J. Coord. Chem. 2007, 33, 208.

4. Prasad, S.; Agarwal, R.K. Res. Lett. Inorg.Chem. 2008, 1.

5. Chohan, Z.H. Appl. Organometal. Chem. 2006, 20, 112.

6. Patrole, J.; Shingapurkar, D.; Padhye, S.; Ratledge, C. Bioorgan Med. Chem. Lett. 2006, 16, 1514.

7. Chohan, Z.H.; Supuran, C.T. Appl. Organnometal. Chem. 2005, 19, 1207.

8. Sari, N.; Arslan, S.; Logoglu, E.; Sakiyan, I. G.U.J. Science 2003, 16, 283.

9. Siddiqui, H.L.; Ahmad, A. I. S.; Waver, G.W. Molecules 2006, 11, 206.

10. Elzaher, M.M.A. Appl. Organometal. Chem. 2004, 18, 149.

11. Canham, G.R.; Overton, T. Descriptive Inorganic Chemistry. 3rd ed., New York: W.H. Freeman and Company; 2003; p 449.

12. Mackay, K.M.; Mackay, R.A.; Henderson, W. Introduction to Modern Inorganic Chemistry. 5th ed., Blackie and Professional: London; 1996; p 416.

13. Dipiro, J.T.; Talbert, R.L.; Yee, G.C.; Matzke, G.R.; Wells, B.G.; Posey, L.M. Pharmacotherapy, A. Pathophysiologic Approach, 3rd ed., A Simon and Schuster Company: New York, USA; 1997.

14. Wolff, M.E. Burger's Medicinal Chemistry, Part II, 4th ed., John Wiley and Sons: New York; 1979.

15. Thimmaiah, K.N.; Horton, J.K.; Seshadri, R.; Israel, M.; Houghton, J.A.; Harwood, F.C.; Houghton, P.J. J. Med. Chem. 1992, 35, 3358.

16. Miller, M.M.; Stineman, C.N.; Vance, J.R.; West, D.X.; Hall, H.I. Appl. Organometal. Chem. 1999, 13, 9.

17. Nath, M.; Yadav, R.; Gielen, M.; Dalil, H.; Vos, D.; Eng, G. Appl. Organometal. Chem. 1997, 11, 727.

18. Pal, S.; Sreerama, G.S. Inorg. Chem. 2002, 41, 4843.

19. Yang, Z.Y.; Yang, R.D.; Li, F.S.; Yu, K.B. Polyhedron 2000, 19, 2599.

20. Singh, B.; Srivastava, K.; Narang, K.K.; Singh, V.P. Synth. React. Inorg. Met-Org. Chem. 1999, 29, 1867.

21. Bernhardt, P.V.; Wilson, J.G.; Sharpe, P.C.; Kalinowski, S.D.; Richardson, R.D. J. Biol. Inorg. Chem. 2008, 13, 107.

22. Bottari, B.; Maccari, R.; Monforte, F.; Ottanà, R.; Rotondo, E.; Vigorita, M.G. Bioorg. Med. Chem. Lett. 2000, 10, 657.

23. Sridhar, S.K.; Saravanan, M.; Ramesh, A. Eur. J. Med. Chem. 2001, 36, 615.

24. Ndifon, P.T.; Agwara, M.O.; Njapba, J.N.; Yufanyi, D.M.; Awawou, P.G.; Nyamen, L.D. Res. J. Chem. Environ. 2010, 14, 50.

25. Agwara, M.O.; Ndifon, P.T.; Ndosiri, N.B.; Paboudam, A.G.; Yufanyi, D.M.; Mohamadou, A. Bull. Chem. Soc. Ethiop. 2010, 24, 383.

26. Agarwal, R.K.; Singh, L.; Sharma, D.K.; Singh, R. Turk. J. Chem. 2005, 29, 309.

27. Berghe, V.A.; Vlietinck, A.J. Methods Biochem. 1991, 6, 47.

28. Geary, W.J. Coord. Chem. Rev. 1971, 7, 81.

29. Duggal, H.K.; Agarwala, M. Synth. React. Inorg. Met-Org.Chem. 1998, $18,871$.

30. Maurya, R.C.; Maurya, M.R. Rev. Inorg. Chem.1995, 15, 101.

31. Nfor, E.N.; Esemu, G.A.; Ayimele, E.A.; Eno, G.E.; Iniama, E.O. Offiong, Bull. Chem. Soc. Ethiop. 2011, 25, 361. 
32. Sharma, K.K.; Singh, R.; Fahmi, N.; Singh, R.V. J. Coord. Chem. 2010, 63, 3071.

33. Kovala-Demertzi, D.; Galani, A.; Korkoumelis, N.; Miller, J.R.; Demertzis, M.A.

Polyhedron 2007, 26, 2871.

34. Mishra, A.K.; Mishra, S.B.; Kaushik, N.K. J. Coord. Chem. 2007, 60, 1691.

35. Ababei, L.V.; Kriza, A.; Andronescu, C.; Musuc, MA. J. Therm. Anal. Colorim. 2011, 1.

36. Lv, L.; Liu, S.C.; Wang, X.; Liu, L.; Wang, Y. J. Inorg. Biochem. 2006, 100, 1888. 